Sains Malaysiana 50(2)(2021): 327-337

http://dx.doi.org/10.17576/jsm-2021-5002-05

\title{
Carotenogenesis in Nannochloropsis oculata under Oxidative and Salinity Stress
}

(Karotenogenesis dalam Nannochloropsis oculata di bawah Tekanan Oksidatif dan Saliniti)

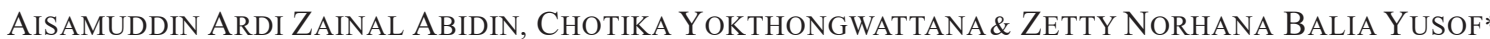

\begin{abstract}
Nannochloropsis oculata is a unicellular microalgae which is vastly found throughout the environment and have been widely studied due to its high productivity of secondary metabolites and oil content. It is majorly cultured in the aquaculture sector as fish feed and for industries for its polyunsaturated fatty acids. This work aims to study the impact of salinity and oxidative stress on the expression of carotenoid biosynthesis genes and the accumulation of their products in N. oculata via QPCR and HPLC analyses. Three genes responsible for production of high value carotenoids namely lycopene beta-cyclase (CrTL-B/LCYB), beta-carotene oxygenase (CrTO) and beta-carotene hydroxylase (CrTR) under different stresses and time points were identified and quantified, and the amount of their products namely $\beta$-carotene, zeaxanthin, canthaxanthin, and astaxanthin was measured. $\mathrm{N}$. oculata was treated with different concentrations of $\mathrm{Cu}^{2+}$ ion $(1,2$, and $5 \mathrm{ppm})$ and $\mathrm{NaCl}(50,150,250 \mathrm{mM})$ which resembles conditions of oxidative and salinity stress, respectively. RNA and carotenoids extraction, RT-PCR, qPCR and HPLC was carried out in order to identify the correlation of carotenogenesis genes expression with carotenoids production. Under exposure of both treatments, the carotenoids biosynthesis genes were upregulated up to 6-fold compared to control and targeted carotenoids were overexpressed up to 7-fold. Results from this study gave insights which are beneficial in understanding microalgae's responses towards abiotic stress via the synthesis of carotenoids.
\end{abstract}

Keywords: Carotenoids; carotenogenesis; Nannochloropsis oculata; oxidative stress; salinity stress

\section{ABSTRAK}

Nannochloropsis oculata ialah mikroalga unisel yang banyak ditemui di alam sekitar dan telah dikaji secara meluas kerana produktiviti tinggi metabolit sekunder dan kandungan minyaknya. Kebanyakannya digunakan di dalam sektor akuakultur sebagai makanan ikan dan di dalam sektor industri untuk asid lemak tak tepu. Kajian ini bertujuan untuk melihat kesan saliniti dan tekanan oksidatif pada pengekspresan gen biosintesis karotenoid dan pengumpulan kandungan karotenoid dalam N. oculata melalui qPCR dan analisis HPLC. Pengekspresan tiga gen yang bertanggungjawab untuk menghasilkan karotenoid bernilai tinggi iaitu beta-siklase likopin (CrTL-B / LCYB), betakaroten oksigen (CrTO) dan beta-karoten hidroksilase (CrTR) telah dianalisa di bawah tekanan yang berbeza dan jumlah penghasilan produk akhir iaitu $\beta$-karoten, zeaxantin, cantaxantin dan astaxantin telah diukur. N. oculata telah dirawat dengan kepekatan ion $\mathrm{Cu}^{2+}$ yang berbeza $(1,2$ dan 5 ppm) dan $\mathrm{NaCl}$ (50, 150, $250 \mathrm{mM}$ ) yang menyerupai keadaan tekanan oksidatif dan salin. Pengekstrakan RNA dan karotenoid, RT-PCR, qPCR dan HPLC dilakukan untuk mengenal pasti korelasi ekspresi gen carotenogen dengan pengeluaran karotenoid. Di bawah pendedahan kedua-dua tekanan, pengekspresan gen biosintesis karotenoid telah meningkat sehingga 6 kali ganda berbanding dengan kawalan dan karotenoid yang dihasilkan meningkat sehingga 7 kali ganda. Keputusan daripada kajian ini memberikan pandangan yang bermanfaat dalam memahami tindak balas mikroalga terhadap tekanan abiotik melalui sintesis karotenoid.

Kata kunci: Karotenoid; karotenogenesis; Nannochloropsis oculata; tekanan oksidatif; tekanan saliniti

\section{INTRODUCTION}

Humans have exploited various carotenoids producers such as microalgae to synthesize carotenoids which are mainly utilized for their antioxidant properties and a source of organic food colourant (Lembi \& Waaland
1988). The current global trade in microalgal carotenoids is estimated to reach $\$ 1,428.12$ million by 2019 (Garg et al. 2015). Microalgae are important source of high-value chemicals such as carotenoids (Borowitzka 2013), longchain polyunsaturated fatty acids (Mendes et al. 2009; 
Ratledge 2004) and phycobilins (Singh et al. 2005). The potential of microalgae as a new source of valuable chemicals and other products has regained wide interest in recent years, especially as a by-product for feedstock and renewable biofuels (Stephens et al. 2010; Wijffles et al. 2010). In Malaysia, not much has been done in utilising microalgae for industrial purposes. However, there are some utilisation especially in developing functional foods and biodiesel from microalgae and other by-products. A lot of research utilising microalgae have been done to improve the quality of aquaculture activities, biodiesel production, water treatment, and bioremediation of heavy metals (Habib et al. 1998; Hossain et al. 2008; Natrah et al. 2007) but it is still a work in progress. Apart from that, there are rising number of publications on locally isolated microalgae strain in Malaysia (Maznah et al. 2012; Milledge 2011) but not much have been done in studying carotenoids production in these locally isolated microalgae.

There are two species of microalgae that are majorly studied and the major contributor to the carotenoids global market which are Dunalella salina and Haematococcus pluvialis (Borowitzka \& Borowitzka 1989; Lorenz \& Cysewski 2000). Genetic studies on carotenoids biosynthesis in microalgae have also been widely studied in D. salina, H. pluvialis, and Chlamydomonas reinhardtii
(Santabarbara 2015; Steinbrenner \& Sandmann 2006; Ye et al. 2008). The search for other potential carotenoid resources from other species of microalgae has also been carried out. However, the drawbacks are that there are no dominant carotenoids synthesised in the other species as compared to D. salina and H. pluvialis which produces dominant pigments which is composed of more than $60 \%$ from the total carotenoids content. Furthermore, most studies on carotenoids production were done under heterotrophic conditions where spontaneous oxidative stress is absent (Ip \& Chen 2005). Oxidative and salinity stress have also been reported to increase thiamine gene expression in plants as well as microalgae (Abidin et al. 2016; Fern et al. 2017) and antioxidant properties in microalgae (Azim et al. 2018). Overall, there is lack of knowledge between gene expression and carotenoids production in microalgae and how it is being regulated in the presence of oxidative and salinity stress. Carotenoids synthesis in all photosynthetic organisms is similar, but in some microalgae and macroalgae they possess additional pigments that differentiate them from higher plants. These pigments include fucoxanthin, astaxanthin, diadinoxanthin, and canthaxanthin (Takaichi 2011). In this project, a section of the carotenoid biosynthesis pathway was focused on as highlighted in the red box in Figure 1.

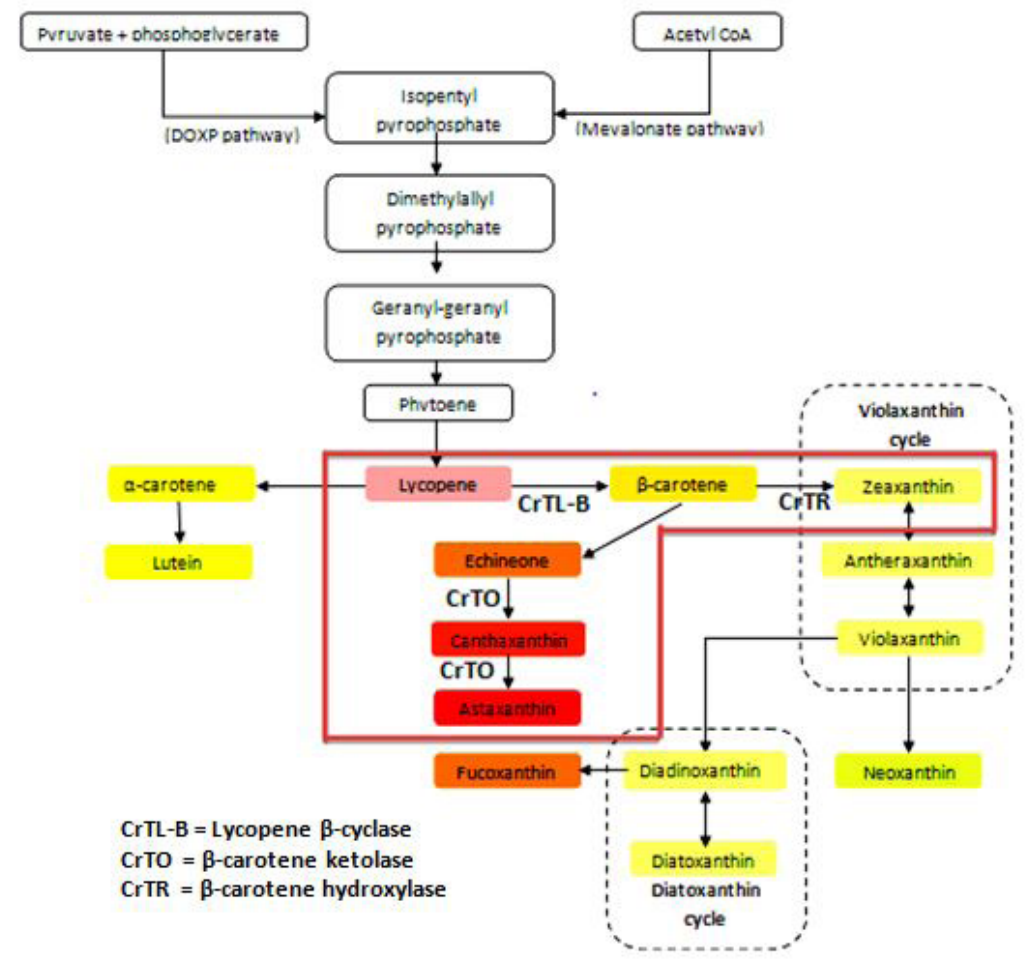

FIGURE 1. A simplified version of carotenoids biosynthesis in microalgae. It is a complex pathway which contains branches and cycles. The red box indicates the section of the pathway that was focused on in this study 
Principally, reactive oxygen species (ROS) production in photosynthetic organisms occurs due to photoinhibition, photorespiration, and presence of ROS generators. Environmental stressors such as osmotic shock, thermal shock, heavy metals, air pollutants (ozone and sulphur dioxide), mechanical stress, UV radiation, nutrient deprivation and high irradiance could disrupt the ROS homeostasis (Mulders et al. 2014) hence, causing oxidative damage. Strategies widely utilised by microalgae to protect itself from oxidative damage include photochemical and nonphotochemical quenching (Ort \& Baker 2002). Microalgae counter the increase in ROS production through increased carotenogenic activity (synthesis of carotenoid pigments), thereby reducing the oxygen concentration in the cell and subsequently reducing ROS formation (Lemoine \& Schoefs 2010). Carotenoid pigments act as photoprotective agents (Mulders et al. 2014) and exhibit antioxidant properties in response to oxidative stress (Chen et al. 2003). Carotenoids pigments such as astaxanthin, $\beta$-carotene, lutein, and neoxanthin act as scavengers and neutralise free radicals of singlet oxygen or ROS preventing cell damage (Tefler et al. 2008). Studies on the role of heavy metals in carotenoid production have been reported to increase carotenogenesis via Fenton reaction (Tjahjono et al. 1994), increase of carotenoids levels in cyanobacterium Spirulina platensis (Goodwin 1980) and increase astaxanthin production in H. pluvialis (Kobayashi et al. 1997). It can be assumed that this positive response was due to a stimulatory effect of cations on carotenoid-synthesizing enzymes, as reported earlier (Goodwin 1980), or to the generation of active oxygen radicals in the culture broth.

Apart from radical or reactive oxygen species, it is also well established that a sharp increase in the concentrations of osmotically active compounds in culture medium enhances carotenoids accumulation in carotenogenic microalgae. In D. salina, after the addition of $\mathrm{NaCl}$ in the lag phase, the activity of carotenogenesis were more favourable in producing $\beta$-carotene (Borowitzka et al. 1990). Under high saline conditions, an increase in $D$. salina's $\beta$-carotene proportions among carotenoids was observed, which indicates a predominant activation of lycopene $\beta$-cyclase under conditions of osmotic stress induced by high $\mathrm{NaCl}$ concentrations. Chlorococcum sp. also showed positive inclination towards carotenoid accumulation in the presence of inorganic salts (Liu \& Lee 2000). It was suggested that osmotic stress is similar towards high light stress that lead to ROS production (Lesser 2006). This study was focused on Nannochloropsis oculata, a green microalga which is strictly photoautotrophic which have been utilised majorly as feed in fish hatcheries in Malaysia (Cremen et al. 2007; Shaari et al. 2011) and also abundantly available in Malaysia's environment (Cremen et al. 2007). Apart from that, Nannochloropsis have also been regarded as model organism for oleaginous microalgae and also green microalgae (Vieler et al. 2012; Wang et al. 2014) where results from this study could simulate the outcome for other microalgae studies.

\section{MATERIALS AND METHODS}

\section{GROWTH OF ALGAL CULTURES AND CULTURE CONDITIONS}

Nannochloropsis oculata was obtained from the locally isolated culture collection in Centre of Marine Sciences (COMAS) of Universiti Putra Malaysia, Teluk Kemang, Port Dickson, Malaysia $\left(2^{\circ} 27 \mathrm{~N}, 101^{\circ} 50 ’ \mathrm{E}\right)$. The microalga is maintained in TAP/2 enriched with seawater media which consist of (per litre): $1.21 \mathrm{~g}$ Tris Base; $12.5 \mathrm{~mL}$ of TAP salts; $0.188 \mathrm{~mL}$ of TAP phosphate; $0.5 \mathrm{~mL}$ of Hutner's Trace Element; $0.5 \mathrm{~mL}$ glacial acetic acid. The $\mathrm{pH}$ of the media was adjusted to $\mathrm{pH} 7.0$ prior to autoclaving at $121^{\circ} \mathrm{C}$ for $20 \mathrm{~min}$. The cultures were cultivated in a 250 $\mathrm{mL}$ Erlenmeyer flask at $24{ }^{\circ} \mathrm{C}$ with continuous shaking at $150 \mathrm{rpm}$. The cultures were illuminated continuously $24 \mathrm{~h}$ under $50 \mu \mathrm{mol}$ photons $\mathrm{m}^{-2} \mathrm{~s}^{-1}$ and the growth were determined by measuring the absorbance at $750 \mathrm{~nm}$ wavelength.

\section{TREATMENT APPLICATION AND SAMPLINGS}

When the cultures reach mid exponential phase $\left(\mathrm{A}_{750}=\right.$ $1.0)$, the algal cultures were treated with two type of stresses namely salinity stress $(\mathrm{NaCl})$ and oxidative stress by heavy metals $\left(\mathrm{Cu}^{2+}\right.$ ion) (Fern et al. 2017) at various concentrations. No application of treatments was regarded as control. Salinity stress was implemented by treating cultures with $\mathrm{NaCl}$ with an additional concentration of 50,150 , and $250 \mathrm{mM}$. On the other hand, cultures were treated with $\mathrm{Cu}^{2+}$ ion to a final concentration of 1,2 , and $5 \mathrm{ppm}$ of $\mathrm{Cu}^{2+}$ to implement oxidative stress. Sampling of each culture was carried out every 2 days up to day 8 but after $30 \mathrm{~min}$ post-addition of stressors for day 0 . Samples were pelleted down and stored in $-80{ }^{\circ} \mathrm{C}$ until used. For carotenoids extraction, $6 \mathrm{~mL}$ of culture was used while 10 $\mathrm{mL}$ of culture was used for RNA extraction.

\section{QUANTITATIVE POLYMERASE CHAIN REACTION (QPCR)}

PGTX extraction protocol was used in this study for RNA extraction where it was shown to be effective in extracting RNA from cyanobacteria compared to other conventional methods (Pinto et al. 2009). The RNA was then dissolved with autoclaved distilled water and stored in $-80^{\circ} \mathrm{C}$ until further analysis. DNAse treatment 
was then carried out to remove DNA contaminants using DNase (Ambigen, UK). RNA obtained was then converted to complementary-DNA (cDNA) by using qPCRBIO cDNA synthesis kit (PCRBiosystems, UK) according the manufacturer manuals. QPCR was then performed using SensiFAST ${ }^{\mathrm{TM}}$ SYBR No-ROX Kit (Bioline, UK) and designed primers as shown in Table 1 . The qPCR protocol is as described by the manufacturer with $0.4 \mu \mathrm{g}$ of cDNA template for each reaction samples using CFX Connect ${ }^{\mathrm{TM}}$ Real-Time PCR machine (Biorad, UK). Each reaction was done in triplicate and the expression of the gene of interest were analysed against a reference gene which was the housekeeping gene, GAPDH. After normalisation, the expression of $G A P D H$ was indicated as zero giving the expression unit of the carotenoid biosynthesis gene of interest in relative quantity as described by Pfaffl (2004).

TABLE 1. Primers used in this study

\begin{tabular}{|c|c|c|}
\hline Gene of interest & Primer sequence & Fragment size (bp) \\
\hline $\begin{array}{l}\text { Glyceraldehyde 3-phosphate } \\
\text { Dehydrogenase (GAPDH) }\end{array}$ & $\begin{array}{l}\text { Forward } \\
\text { CGGTTCTCTCGTGGG } \\
\text { Reverse } \\
\text { CCTGTGTGTCCACGG }\end{array}$ & 100 \\
\hline Lycopene $\beta$-cyclase (CrTL-B) & $\begin{array}{l}\text { Forward } \\
\text { TGATAGCTGATTTACGTCTT } \\
\text { Reverse } \\
\text { CCGCAAATTTTACCATATTTC }\end{array}$ & 100 \\
\hline B-carotene ooxygenase (CrTO) & $\begin{array}{l}\text { Forward } \\
\text { TTTTTAATATGGGCTTCTGC } \\
\text { Reverse } \\
\text { GGGTTTATTAATTAGGATTGG }\end{array}$ & 100 \\
\hline B-carotene hydroxylase (CrTR) & $\begin{array}{l}\text { Forward } \\
\text { CAAACAAGCAGGCAATG } \\
\text { Reverse } \\
\text { CAAACCTCTCCCAACCC }\end{array}$ & 100 \\
\hline
\end{tabular}

\section{CAROTENOIDS EXTRACTION SAMPLES AND STANDARDS} PREPARATION FOR HPLC ANALYSIS

$\beta$-carotene (Sigma-Aldrich), astaxanthin (SigmaAldrich), cantaxanthin (Thomas Scientific), and zeaxanthin (Sigma-Aldrich) pigments standards were purchased for HPLC analyses. Standards were mixed with $100 \%$ acetone to give the final concentration prior to injection into the HPLC. For sample extraction process, $10 \mathrm{~mL}$ of $100 \%$ acetone was added to the sample and sonicated at $0{ }^{\circ} \mathrm{C}$ (ice-water bath) for $15 \mathrm{~min}$. The extract was incubated overnight in darkness at $-20^{\circ} \mathrm{C}$. The samples were vortexed for $20 \mathrm{~s}$ and centrifuged at $2500 \mathrm{rpm}$ for $5 \mathrm{~min}$. After centrifugation, the supernatant was transferred to a new tube and the volume was made up to $10 \mathrm{~mL}$ using $100 \%$ acetone. The tube was then stored at $-20{ }^{\circ} \mathrm{C}$ until analysis.
Prior to analysis, a $0.2 \mu \mathrm{m}$ syringe filter was rinsed with $100 \%$ acetone and $1 \mathrm{~mL}$ of the extract was filtered into an amber coloured HPLC vial up to the $1 \mathrm{~mL}$ mark. The vial was then placed into the HPLC machine for HPLC analysis.

\section{HPLC ANALYSIS FOR CAROTENOID PIGMENTS}

Carotenoids production were analysed based on a HPLC analysis protocol by Van Heukelem and Thomas (2001). Lunar $\mathrm{C}_{8}$ column with a dimension of $150 \times 4.6(\mathrm{~mm})$ was used in this study for HPLC analysis. The column was then placed tightly in a HPLC machine (Agilent Technologies, 1200 Series) from Agilent Company. The Agilent HPLC machine was equipped with a UV-visible light detector set to monitor $450 \mathrm{~nm}$ and above, auto injector $(100 \mu \mathrm{L}$ 
loop) and an external column heating device. There were two types of mobile phase used in the analyses: Solvent A was 70:30 (v/v) methanol, $28 \mathrm{mM}$ aqueous tetrabutyl ammonium acetate (TBAA), $\mathrm{pH} 6.5$; Solvent B was $100 \%$ methanol. Samples were mixed with buffer (28 mM TBAA, $\mathrm{pH}$ 6.5) (1:1) and manually injected into the HPLC machine for each samples respectively. The flow rate of the mobile phase was $1.1 \mathrm{~mL} \mathrm{~min}^{-1}$ and the column temperature was set to $60{ }^{\circ} \mathrm{C}$. Mobile gradient was implemented in the HPLC run where initially $95 \%$ solvent A and 5\% solvent B (0 min) and a linear gradient 5 to $95 \%$ solvent B was used in $22 \mathrm{~min}$, followed by an isocratic hold for $7 \mathrm{~min}$ and returned to initial conditions in $2 \mathrm{~min}$. The total HPLC run time was $30 \mathrm{~min}$ with an injection volume of $10 \mu \mathrm{L}$. Each sample and standard peak were detected at $450 \mathrm{~nm}$ wavelength.

\section{RESULTS AND DISCUSSION}

GROWTH OF CULTURE UNDER TREATMENT APPLICATION

Figure 2 shows the cultures were treated with $\mathrm{Cu}^{2+}$ ion for oxidative stress induction and with $\mathrm{NaCl}$ for salinity stress induction where the cells activity was high during mid-exponential stage together with controls culture where no stressors were added. Under both stresses the growth of the cultures were partially suppressed compared to the control. This showed that presence of the stressors actually affects the growth of the cultures. Based on previous trials, the $N$. oculata culture could not survive under the condition of $10 \mathrm{ppm}$ of $\mathrm{Cu}^{2+}$ ion (data not shown). The growth was completely inhibited with no sign of growth even after 2 days post-inoculation. However, at $5 \mathrm{ppm}$ and below, there were signs of growth in the culture. $\mathrm{Cu}^{2+}$ has been showed to be absorbed by Nannochloropsis species and inhibited the growth (Khairy 2009). $\mathrm{NaCl}$ on the other hand have also shown to be inhibiting Nannochloropsis sp. growth (Pal et al. 2011) although it is a part of its macronutrient. High absorption or influnction of these ions may disrupt the ROS homeostasis and lead to high production of ROS which supress the growth of the organism (Erdmann \& Hagemann 2001).
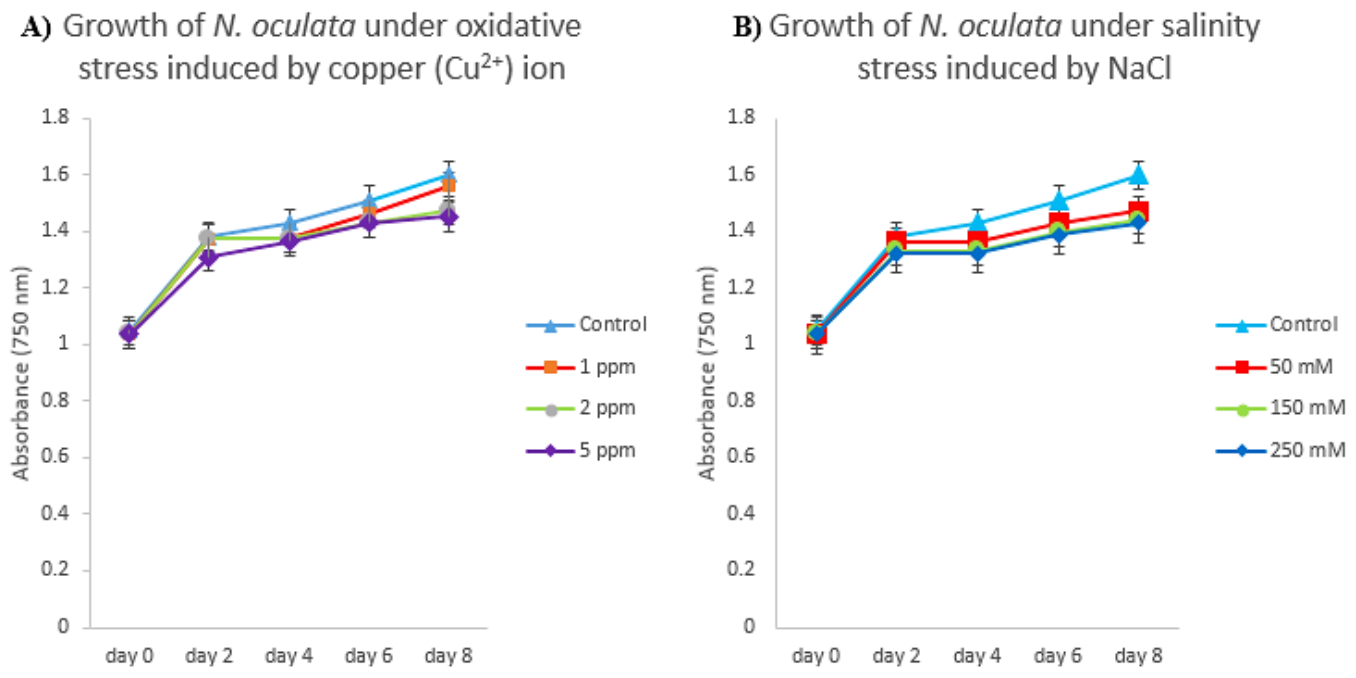

FIGURE 2. A) The growth of $N$. oculata under oxidative stress induced by copper $\left(\mathrm{Cu}^{2+}\right)$ ion at $0,1,2$ and $5 \mathrm{ppm}$, and B) The growth of $N$. oculata under salinity stress induced by $\mathrm{NaCl}$ at $0,50,150$ and $250 \mathrm{mM} . n=3$. Error bars represent SEM

\section{CAROTENOGENESIS OF N. oculata UNDER OXIDATIVE STRESS}

After the normalisation against the reference gene, the relative expression of the targeted genes under oxidative and salinity stress in $N$. oculata was obtained as shown in Figure 3. The results showed that under oxidative stress, all targeted genes expression were upregulated compared to control. Under oxidative stress, CrTR gene was the highest upregulated gene compared to CrTL-B gene. Apart from that, the carotenoid production however shows a constant production of $\beta$-carotene and a steady upregulation of zeaxanthin production up to day 6 . Zeaxanthin was found to be the most accumulated in the microalgae at $72.3 \mu \mathrm{g} \mathrm{mL}^{-1}$ under $2 \mathrm{ppm}$ of copper on day 6 while $\beta$-carotene at $59 \mu \mathrm{g} \mathrm{mL}^{-1}$ under $5 \mathrm{ppm}$ of copper (Table 2). 
A) CrTL-B - Lycopene $\beta$-cyclase

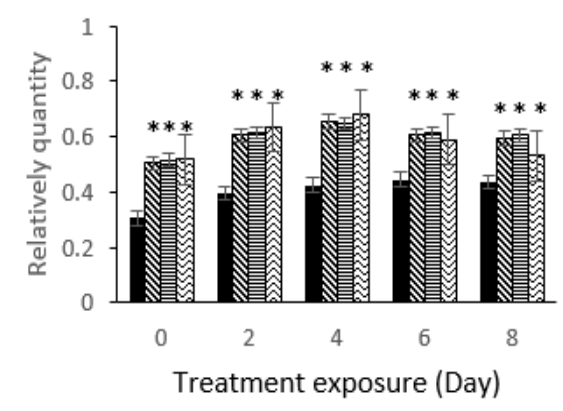

C) CrTR - $\beta$-carotene

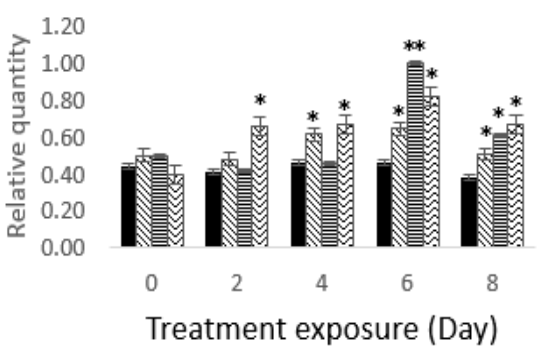

B) CrTO - Beta carotene

ooxygenase

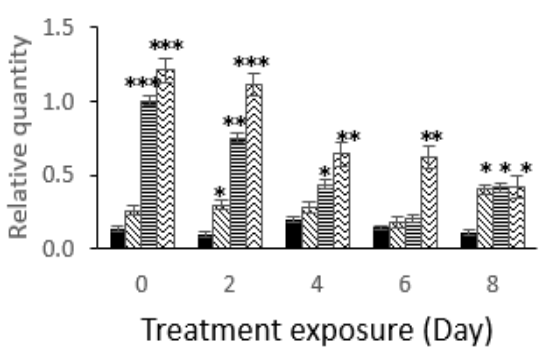

Control $\mathbb{N}$ Copper 1 ppm 嘈Copper 2 ppm 图Copper 5 ppm

FIGURE 3. qPCR analyses of A) $C r T L-B$; B) $C r T R$ and C) $C r T O$ genes expression under oxidative stress. $\mathrm{n}=3$ replicates. Error bars represent SEM. ${ }^{*} \mathrm{p}<0.05,{ }^{* *} \mathrm{p}<0.01$ and $* * * \mathrm{p}<0.001$ versus control (untreated cultures), using one-way ANOVA (Dunnett post-test) on the raw data

TABLE 2. Analyses productions of $\beta$-carotene, zeaxanthin, canthaxanthin, and astaxanthin under oxidative stress using HPLC. Data are expressed as mean \pm SEM. ${ }^{*} \mathrm{p}<0.05,{ }^{*} \mathrm{p}<0.01$ and $* * * \mathrm{p}<0.001$ versus control (untreated cultures) at each representative day, using one-way ANOVA (Dunnett post-test) on the raw data

\begin{tabular}{|c|c|c|c|c|c|}
\hline \multirow{2}{*}{$\begin{array}{c}\text { Treatment } \\
\text { exposure (Day) }\end{array}$} & \multirow{2}{*}{$\begin{array}{c}\text { Copper } \\
\text { concentration }(\mathrm{ppm})\end{array}$} & \multicolumn{4}{|c|}{ Carotenoid pigment $\left(\mu \mathrm{g} \mathrm{mL}^{-1}\right)$} \\
\hline & & $\beta$-carotene & Zeaxanthin & Cantaxanthin & Astaxanthin \\
\hline \multirow{4}{*}{0} & 0 & $31.2 \pm 0.12$ & $33.2 \pm 0.12$ & $2 \pm 0.42$ & $5.3 \pm 0.32$ \\
\hline & 1 & $49.5 \pm 0.42 *$ & $46.8 \pm 0.42 *$ & $15 \pm 0.12 *$ & $6 \pm 0.42$ \\
\hline & 2 & $50.4 \pm 0.41^{*}$ & $45.3 \pm 0.41^{*}$ & $28.6 \pm 0.51 * *$ & $17.3 \pm 0.71^{* *}$ \\
\hline & 5 & $50.2 \pm 0.13^{*}$ & $45.7 \pm 0.13^{*}$ & $29.1 \pm 0.13^{* *}$ & $15.8 \pm 0.13^{* *}$ \\
\hline \multirow{4}{*}{2} & 0 & $32.7 \pm 0.47$ & $33.3 \pm 0.47$ & $4.3 \pm 0.34$ & $6.1 \pm 0.0$ \\
\hline & 1 & $51.1 \pm 0.66^{*}$ & $47.1 \pm 0.66^{*}$ & $15.7 \pm 0.44 *$ & $17 \pm 0.34 * *$ \\
\hline & 2 & $52.3 \pm 0.87^{*}$ & $48.7 \pm 0.87^{*}$ & $18.2 \pm 0.41^{*}$ & $26.4 \pm 1.44 * * *$ \\
\hline & 5 & $52.9 \pm 0.89^{*}$ & $48.9 \pm 0.88^{*}$ & $21.7 \pm 1.8^{* *}$ & $25.9 \pm 1.88^{* * *}$ \\
\hline \multirow{4}{*}{4} & 0 & $35 \pm 0.49$ & $38.4 \pm 0.43$ & $3.75 \pm 0.47$ & $6.1 \pm 0.43$ \\
\hline & 1 & $53.1 \pm 0.65^{*}$ & $52 \pm 0.43 *$ & $13.56 \pm 0.66^{*}$ & $15.2 \pm 0.43 * *$ \\
\hline & 2 & $54.7 \pm 0.53 *$ & $57.7 \pm 0.77^{*}$ & $15.1 \pm 0.87^{*}$ & $25.1 \pm 0.77 * * *$ \\
\hline & 5 & $56.3 \pm 0.65^{*}$ & $55.5 \pm 0.66^{*}$ & $17.3 \pm 0.88^{*}$ & $25.7 \pm 1.88^{* * *}$ \\
\hline \multirow{4}{*}{6} & 0 & $30.3 \pm 0.43$ & $36.5 \pm 0.34$ & $3.5 \pm 0.43$ & $6 \pm 0.49$ \\
\hline & 1 & $55 \pm 0.43 *$ & $65 \pm 0.44 *$ & $11.4 \pm 0.43^{*}$ & $8.3 \pm 0.65$ \\
\hline & 2 & $58 \pm 0.77^{*}$ & $72.3 \pm 0.66^{* *}$ & $11.2 \pm 0.77^{*}$ & $17 \pm 1.53^{* *}$ \\
\hline & 5 & $59 \pm 0.87 *$ & $66 \pm 0.88^{*}$ & $13.6 \pm 0.88^{*}$ & $14.3 \pm 0.65^{*}$ \\
\hline
\end{tabular}


Based on the focused pathway (Figure 1), the CrTL-B expression leads to the production of $\beta$-carotene and CrTR that leads to the production of zeaxanthin. Under oxidative stress, the expression of $C r T L-B$ together with the production $\beta$-carotene was increased when compared to control which indicates that there was an induction of carotenogenesis in the presence of oxidative stress by copper. The correlation between gene expression and carotenoids production were studied based on the gene expression. Expression of CrTR leads to the formation of zeaxanthin from $\beta$-carotene. Our data showed a high upregulation of the gene expression on day 6 which correlate with the pattern observed for zeaxanthin production. The highest production of zeaxanthin was 72.3 $\mu \mathrm{g} \mathrm{mL}{ }^{-1}$ on day 6 under 2 ppm of $\mathrm{Cu}^{2+}$ ion treatment. A study on copper toxicity effect on pigments in Crassula helmsii, a macrophyte, showed most pigments were degraded under the exposure of the copper. However, $\beta$-carotene and zeaxanthin showed slower degradation (Küpper et al. 2009). Azim et al. reported in 2018 where $N$. oculata total phenolic content as well as radical scavenging activity increases more than $30 \%$ in comparison to control under 5 and $2 \mathrm{ppm}$ of $\mathrm{Cu}^{2+}$ ion. Carotenoids together with zeaxanthin might contribute to the outcome of the results as they also fall under phenolic compounds and antioxidant properties compounds. In conjunction with the results obtained, probably zeaxanthin was highly expressed in order to counter back copper damaging effect more effectively compared to other pigments.

\section{CAROTENOGENESIS OF $N$. oculata UNDER SALINITY STRESS}

On the other hand, carotenoids biosynthesis genes expression under salinity stress shows a reverse pattern initially, as CrTO gene was highly upregulated at day 0 but the expression decreases throughout the treatment period. Towards the end of the treatment period under oxidative stress, CrTO gene was the highest upregulated gene among the targeted genes. However, overall carotenoids biosynthesis genes expressions were higher compared to control (Figure 4). Under salinity stress, $\beta$-carotene was found to be the most accumulated in the microalgae at $53.3 \mu \mathrm{g} \mathrm{mL}^{-1}$ under 250 and $150 \mathrm{mM}$ of $\mathrm{NaCl}$ at day 4 and 6 , respectively. Zeaxanthin highest production was $49 \mu \mathrm{g} \mathrm{mL}-1$ under $250 \mathrm{mM}$ of $\mathrm{NaCl}$ on day 2, while astaxanthin $\left(45.3 \mu \mathrm{g} \mathrm{mL}^{-1}\right)$ under $250 \mathrm{mM}$ of $\mathrm{NaCl}$ at day 6 and canthaxanthin $(36.9 \mu \mathrm{g} \mathrm{mL}-1)$ under $250 \mathrm{mM}$ of $\mathrm{NaCl}$ at day 2 (Table 3). Despite the accumulation of the carotenoids, there was some visible pattern of the carotenogenesis shown. Under salinity stress, constant production was measured for $\beta$-carotene and zeaxanthin and steady upregulation of astaxanthin and canthaxanthin from day 0 to day 6 . In comparison towards carotenoids accumulation under oxidative stress, cantaxanthin and astaxanthin accumulated more.
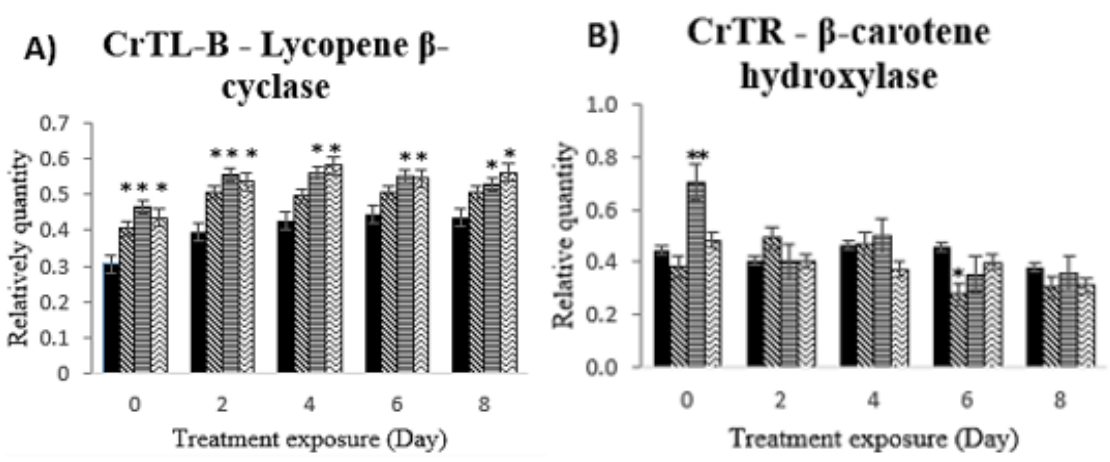

\section{C) CrTO - Beta carotene oxygenase}

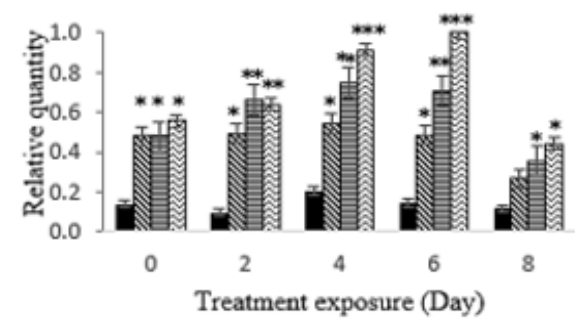

Control $\mathbb{N} \mathrm{NaCl} 50 \mathrm{mM}$ 冒 $\mathrm{NaCl} 150 \mathrm{mM}$ 图 $\mathrm{NaCl} 250 \mathrm{mM}$

FIGURE 4. qPCR Analyses of A) CrTL-B; B) CrTR and C) CrTO genes expression under salinity stress. $\mathrm{n}=3$ replicates. Error bars represent SEM. ${ }^{*} \mathrm{p}<0.05,{ }^{*} \mathrm{p}<0.01$ and $* * * \mathrm{p}<0.001$ versus control (untreated cultures), using one-way ANOVA (Dunnett post-test) on the raw data 
TABLE 3. Analyses productions of $\beta$-carotene, zeaxanthin, canthaxanthin, and astaxanthin under oxidative stress using HPLC. Data are expressed as mean \pm SEM. $* p<0.05, * * p<0.01$ and $* * * p<0.001$ versus control (untreated cultures) at each representative day, using one-way ANOVA (Dunnett post-test) on the raw data

\begin{tabular}{|c|c|c|c|c|c|}
\hline \multirow{2}{*}{$\begin{array}{c}\text { Treatment } \\
\text { exposure (Day) }\end{array}$} & \multirow{2}{*}{$\begin{array}{l}\mathrm{NaCl} \text { concentration } \\
(\mathrm{mM})\end{array}$} & \multicolumn{4}{|c|}{ Carotenoid pigment $\left(\mu \mathrm{g} \mathrm{mL}^{-1}\right)$} \\
\hline & & $\beta$-carotene & Zeaxanthin & Cantaxanthin & Astaxanthin \\
\hline \multirow{4}{*}{0} & 0 & $31.2 \pm 0.12$ & $33.2 \pm 0.12$ & $2 \pm 0.42$ & $5.3 \pm 0.32$ \\
\hline & 50 & $48.4 \pm 0.85^{*}$ & $44.3 \pm 0.45^{*}$ & $17 \pm 0.45^{*}$ & $13 \pm 0.45^{*}$ \\
\hline & 150 & $42.2 \pm 0.2 *$ & $46.3 \pm 0.12 *$ & $21.5 \pm 0.12^{*}$ & $21.3 \pm 1.1^{*}$ \\
\hline & 250 & $49.1 \pm 0.01 *$ & $47.1 \pm 0.34^{*}$ & $23.3 \pm 0.98^{*}$ & $24.4 \pm 1.63 *$ \\
\hline \multirow{4}{*}{2} & 0 & $32.7 \pm 0.47$ & $33.3 \pm 0.47$ & $4.3 \pm 0.34$ & $6.1 \pm 0.0$ \\
\hline & 50 & $50.4 \pm 0.92 *$ & $44.8 \pm 0.42 *$ & $34.3 \pm 0.54^{* *}$ & $23.3 \pm 2.88^{*}$ \\
\hline & 150 & $51.8 \pm 0.48^{*}$ & $46.8 \pm 0.48^{*}$ & $36.4 \pm 0.65^{* *}$ & $29.2 \pm 1.54 * *$ \\
\hline & 250 & $51.7 \pm 0.34^{*}$ & $49 \pm 0.34 *$ & $36.9 \pm 0.88^{* *}$ & $31.9 \pm 0.65^{* *}$ \\
\hline \multirow{4}{*}{4} & 0 & $35 \pm 0.49$ & $38.4 \pm 0.43$ & $3.75 \pm 0.47$ & $6.1 \pm 0.43$ \\
\hline & 50 & $51 \pm 1.0 *$ & $45.1 \pm 0.55^{*}$ & $22 \pm 0.42 *$ & $31.7 \pm 0.55^{* *}$ \\
\hline & 150 & $52.2 \pm 0.34^{*}$ & $47.3 \pm 0.46^{*}$ & $25 \pm 0.88 *$ & $35.3 \pm 0.49 * * *$ \\
\hline & 250 & $53.3 \pm 0.66^{*}$ & $48.3 \pm 0.53 *$ & $24.7 \pm 0.34^{*}$ & $40.3 \pm 0.99 * * *$ \\
\hline \multirow{4}{*}{6} & 0 & $30.3 \pm 0.43$ & $36.5 \pm 0.34$ & $3.5 \pm 0.43$ & $6 \pm 0.49$ \\
\hline & 50 & $51.5 \pm 1.0 *$ & $48.3 \pm 0.54 *$ & $18.2 \pm 0.55^{*}$ & $42 \pm 0.47 * * *$ \\
\hline & 150 & $53.3 \pm 0.55^{*}$ & $48.7 \pm 0.65^{*}$ & $23.2 \pm 1.99 *$ & $40.7 \pm 0.34 * * *$ \\
\hline & 250 & $52.9 \pm 0.99 *$ & $48 \pm 0.88^{*}$ & $23.7 \pm 1.4^{*}$ & $45.3 \pm 1.66 * * *$ \\
\hline
\end{tabular}

Under salinity stress, a similar pattern was observed for $C r T L-B$ gene expression and $\beta$-carotene where there was an increase when compared to the control. On the other hand, CrTR gene expression was highly expressed initially, but showed a decrease in expression towards the end of the treatment period. However, the decrease in CrTR gene expression did not reduce the accumulation of zeaxanthin but a constant was observed production during the treatment period around $45-49 \mu \mathrm{g} \mathrm{mL}^{-1}$ under various concentration of $\mathrm{NaCl}$. This result may be due to the fact that the $C r T R$ gene product or enzyme is not regulated at the transcription level but at post-transcriptional level. However, further analysis should be carried out to support the theory. A similar study in comparison to this study was previously carried out on a cyanobacterium, Anabaena doliolum, where salinity stress and oxidative stress by copper were carried out on the cyanobacterium and showed an induction of total carotenoids (Mallick 2004). Chlorella vulgaris, a chlorophyta microalga, was also treated with different concentration of $\mathrm{Cu}^{2+}$ and a tremendous accumulation of total carotenoids from increased up to more than $300 \mu \mathrm{g} \mathrm{mL}^{-1}$ after 14 days of exposure were observed (Sarada et al. 2002). A distinct relative in the microalgae kingdom, Haematococcus pluvialis, showed astaxanthin accumulation was increased under salinity stress (Srivastava et al. 2005). It is hypothesized that in $N$. oculata other pigments was highly produced via zeaxanthin (as the precursor (Figure 1)) which may function in combating salinity stress. Apart from that, a study on salinity effect on carotenogeneis in N. oculata has showed an increase of accumulation of total carotenoids upon the increase of $\mathrm{NaCl}$ concentrations ( $\mathrm{Gu}$ et al. 2012). On the other hand, a study conducted by Lubian et al. (2000) using different strains of Nannochloropsis showed that an increase of zeaxanthin by 2-fold (Lubián et al. 2000).

\section{CONCLUSION}

All in all, the results obtained suggested that under oxidative stress, the carotenoids biosynthesis pathway in N. oculata is more dominant in expressing CrTR gene and producing zeaxanthin in combating the oxidative effect. However, under salinity stress, it showed higher expression of CrTO. This study supports the hypothesis 
that carotenoids production increases or up-regulated in response to oxidative and salinity stress. The outcome of this study also showed that some carotenoids biosynthesis gene ( $C r T L-B$ and $C r T O$ ) have strong relationship with the carotenoids produced which means that the carotenoids production is regulated at the transcriptional level. This study also showed that the production of zeaxanthin and possibly astaxanthin were not regulated at the transcription level and may be regulated by other factors which have not been addressed in this study. Further studies need to be carried out to understand more on the regulation. This study has been focusing on $N$. oculata, but presumably similar results could be obtained from other species of microalgae. Combination of treatments and further molecular studies on the carotenoids biosynthesis genes should be done in order to understand further on the carotenoid's biosynthesis pathway, its regulation and the relationship between gene expression and carotenoid production.

\section{ACKNOWLEDGEMENTS}

This work was carried out at the Department of Biochemistry, Faculty of Biotechnology and Biomolecular Sciences, Universiti Putra Malaysia with the financial the support of 'Higher Institution Centre of Excellence (HICOE) Research Grant (Fish Vaccine and Therapeutics)', 'Science and Technology Research Partnership for Sustainable Development (SATREPS) Research Grant (Project No. 6300866)' and 'Skim Kecemerlangan Penyelidik 2018 Universiti Putra Malaysia (Project No. 9001101)'.

\section{REFERENCES}

Abidin, A.A.Z., Wong, S.Y., Rahman, N.S.A., Idris, Z.H.C. \& Balia Yusof, Z.N. 2016. Osmotic, oxidative and salinity stresses upregulate the expressions of thiamine (Vitamin B1) biosynthesis genes (THIC and THI1/THI4) in oil palm (Elaies guineensis). Journal of Oil Palm Research 28(28): 308-319.

Azim, N.H., Subki, A. \& Yusof, Z.N.B. 2018. Abiotic stresses induce total phenolic, total flavonoid and antioxidant properties in Malaysian indigenous microalgae and cyanobacterium. Malaysian Journal of Microbiology 14(1): 25-33.

Borowitzka, M.A. 2013. High-value products from microalgaetheir development and commercialisation. Journal of Applied Phycology 25(3): 743-756.

Borowitzka, M.A., Borowitzka, L.J. \& Kessly D. 1990. Effects of salinity increase on carotenoid accumulation in the green alga Dunaliella salina. Journal of Applied Phycology 2(2): 111-119.

Borowitzka, L.J. \& Borowitzka, M.A. 1989. $\beta$-carotene (provitamin A) production with algae. Biotechnology of vitamins, pigments and growth factors. In Elsevier Applied
Biotechnology Series, edited by Borowitzka: Elsevier. pp. 15-26.

Cremen, M.C.M., Martinez-Goss, M.R., Corre Jr., V.L. \& Azanza, R.V. 2007. Phytoplankton bloom in commercial shrimp ponds using green-water technology. Journal of Applied Phycology 19(6): 615-624.

Chen, Y., Li, D., Lu, W., Xing, J., Hui, B. \& Han, Y. 2003. Screening and characterization of astaxanthinhyperproducing mutants of Haematococcus pluvialis. Biotechnolology Letters 25(7): 527-529.

Erdmann, N. \& Hagemann, M. 2001. Salt acclimation of algae and cyanobacteria: A comparison. In Algal Adaptation to Environmental Stresses, edited by Erdmann, N. \& Hagemann M. Berlin, Heidelberg: Springer. pp. 323-361.

Fern, L.L., Abidin, A.A.Z. \& Yusof, Z.N.B. 2017. Upregulation of thiamine (vitamin B1) biosynthesis gene upon stress application in Anabaena sp. and Nannochloropsis oculata. Journal of Plant Biotechnology 44(4): 462-471.

Garg, S., Wang, L. \& Schenk, P.M. 2015. Flotation separation of marine microalgae from aqueous medium. Separation and Purification Technology 156: 636-641.

Goodwin, T.W. 1980. Biosynthesis of carotenoids. In The Biochemistry of the Carotenoids, edited by Goodwin, T.W. Dordrecht: Springer. pp. 33-76.

Gu, N., Lin, Q., Li, G., Qin, G., Lin, J. \& Huang, L. 2012. Effect of salinity change on biomass and biochemical composition of Nannochloropsis oculata. Journal of World Aquaculture Society 43(1): 97-106.

Habib, M.A.B., Phang, S.M., Kamarudin, M.S. \& Mohamed, S. 1998. Chemical characteristics and essential nutrients of agro-industrial effluents in Malaysia. Asian Fisheries 11(3-4): 279-286.

Hossain, A.B.M.S., Salleh, A., Boyce, A.N., Chowdhury, P. \& Naqiuddin, M. 2008. Biodiesel fuel production from algae as renewable energy. American Journal of Biochemistry and Biotechnology 4(3): 250-254.

Ip, P.F. \& Chen, F. 2005. Employment of reactive oxygen species to enhance astaxanthin formation in Chlorella zofingiensis in heterotrophic culture. Process Biochemistry 40(11): 3491-3496

Khairy, H.M. 2009. Toxicity and accumulation of copper in Nannochloropsis oculata (Eustigmatophyceae, Heterokonta). World Applied Science Journal 6(3): 378384.

Kobayashi, M., Kurimura, Y. \& Tsuji, Y. 1997. Lightindependent, astaxanthin production by the green microalga Haematococcus pluvialis under salt stress. Biotechnology Letters 19(6): 507-509.

Küpper, H., Götz, B., Mijovilovich, A., Küpper, F.C. \& MeyerKlaucke, W. 2009. Complexation and toxicity of copper in higher plants. I. Characterization of copper accumulation, speciation, and toxicity in Crassula helmsii as a new copper accumulator. Plant Physiology 151(2): 702-714.

Lembi, C.A. \& Waaland, J.R. 1988. Algae and Human Affairs. New York: Cambridge University Press. pp. 87-181.

Lemoine, Y. \& Schoefs, B. 2010. Secondary ketocarotenoid astaxanthin biosynthesis in algae: A multifunctional 
response to stress. Photosynthesis Research 106(1-2): 155177.

Lesser, M.P. 2006. Oxidative stress in marine environments: Biochemistry and physiological ecology. Annual Review of Physiology 68: 253-278.

Liu, B.H. \& Lee, Y.K. 2000. Secondary carotenoids formation by the green alga Chlorococcum sp. Journal of Applied Phycology 12(3-5): 301-307.

Lorenz, R.T. \& Cysewski, G.R. 2000. Commercial potential for Haematococcus microalgae as a natural source of astaxanthin. Trends in Biotechnology 18(4): 160-167.

Lubián, L.M., Montero, O., Moreno-Garrido, I., Huertas, I.E., Sobrino, C., González-del Valle, M. \& Parés, G. 2000. Nannochloropsis (Eustigmatophyceae) as source of commercially valuable pigments. Journal of Applied Phycology 12(3-5): 249-255.

Mallick, N. 2004. Copper-induced oxidative stress in the chlorophycean microalga Chlorella vulgaris: Response of the antioxidant system. Journal of Plant Physiology 161(5): 591-597.

Maznah, W.W., Al-Fawwaz, A.T. \& Surif, M. 2012. Biosorption of copper and zinc by immobilised and free algal biomass, and the effects of metal biosorption on the growth and cellular structure of Chlorella sp. and Chlamydomonas sp. isolated from rivers in Penang, Malaysia. Journal of Environmental Sciences 24(8): 1386-1393.

Milledge, J.J. 2011. Commercial application of microalgae other than as biofuels: A brief review. Reviews in Environmental Science Biotechnology 10(1): 31-41.

Mendes, A., Reis, A., Vasconcelos, R., Guerra, P. \& Da Silva, T.L. 2009. Crypthecodinium cohnii with emphasis on DHA production: A review. Journal of Applied Phycology 21(2): 199-214.

Mulders, K.J., Lamers, P.P., Martens, D.E. \& Wijffels, R.H 2014. Phototrophic pigment production with microalgae: Biological constraints and opportunities. Journal of Phycology 50(2): 229-242.

Natrah, F.M.I., Yusoff, F.M., Shariff, M., Abas, F. \& Mariana, N.S. 2007. Screening of Malaysian indigenous microalgae for antioxidant properties and nutritional value. Journal of Applied Phycology 19(6): 711-718.

Ort, D.R. \& Baker, N.R. 2002. A photoprotective role for $\mathrm{O}_{2}$ as an alternative electron sinks in photosynthesis? Current Opinion in Plant Biology 5(3): 193-198.

Pal, D., Khozin-Goldberg, I., Cohen, Z. \& Boussiba, S. 2011. The effect of light, salinity and nitrogen availability on lipid production by Nannochloropsis sp. Applied Microbioliogy and Biotechnology 90(4): 1429-1441.

Pfaffl, M.W. 2004. Quantification strategies in real-time PCR. In Applied Microbiology, edited by Pfaffl, M.W. Semantic Scholar. pp. 53-62.

Pinto, F.L., Thapper, A., Sontheim, W. \& Lindblad, P. 2009. Analysis of current and alternative phenol based RNA extraction methodologies for cyanobacteria. BMC Molecular Biology 10(1): 79 .

Ratledge, C. 2004. Fatty acid biosynthesis in microorganisms being used for single cell oil production. Biochimie 86(11): 807-815.
Santabarbara, S., Agostini, A., Casazza, A.P., Zucchelli, G. \& Carbonera, D. 2015. Carotenoid triplet states in photosystem II: Coupling with low-energy states of the core complex. BBA-Bioenergetics 1847(2): 262-275.

Sarada, R., Tripathi, U. \& Ravishankar, G.A. 2002. Influence of stress on astaxanthin production in Haematococcus pluvialis grown under different culture conditions. Process Biochemistry 37(6): 623-627.

Shaari, A.L., Surif, M., Latiff, F.A., Omar, W.M.W. \& Ahmad, M.N. 2011. Monitoring of water quality and microalgae species composition of Penaeus monodon ponds in Pulau Pinang, Malaysia. Tropical Life Sciences Research 22(1): 51-69.

Singh, S., Kate, B.N. \& Banerjee, U.C. 2005. Bioactive compounds from cyanobacteria and microalgae: An overview. Critical Reviews in Biotechnology 25(3): 73-95.

Srivastava, A.K., Bhargava, P. \& Rai, L.C. 2005. Salinity and copper-induced oxidative damage and changes in the antioxidative defence systems of Anabaena doliolum. World Journal of Microbioliogy and Biotechnology 21(6-7): 1291-1298.

Steinbrenner, J. \& Sandmann, G. 2006. Transformation of the green alga Haematococcus pluvialis with a phytoene desaturase for accelerated astaxanthin biosynthesis. Applied and Environmental Microbiology 72(12): 74777484.

Stephens, E., Ross, I.L., King, Z., Mussgnug, J.H., Kruse, O., Posten, C., Borowitzka, M.A. \& Hankamer, B. 2010. An economic and technical evaluation of microalga biofuels. Nature Biotechnology 28(2): 126-128.

Takaichi, S. 2011. Carotenoids in algae: Distributions, biosynthesis and functions. Marine Drugs 9(6): 1101-1118.

Telfer, A. 2005. Too much light? How $\beta$-carotene protects the photosystem II reaction centre. Photochemical and Photobiological Sciences 4(12): 950-956.

Tjahjono, A.E., Hayama, Y., Kakizono, T., Terada, Y., Nishio, N. \& Nagai, S. 1994. Hyper-accumulation of astaxanthin in a green alga Haematococcus pluvialis at elevated temperatures. Biotechnology Letters 16(2): 133-138.

Van Heukelem, L. \& Thomas, C.S. 2001. Computer-assisted high-performance liquid chromatography method development with applications to the isolation and analysis of phytoplankton pigments. Journal of Chromatography A 910(1): 31-49.

Vieler, A., Wu, G., Tsai, C.H., Bullard, B., Cornish, A.J., Harvey, C. \& Campbell, M.S. 2012. Genome, functional gene annotation, and nuclear transformation of the heterokont oleaginous alga Nannochloropsis oceanica CCMP1779. PLoS Genetics 8(11): e1003064.

Wang, D., Ning, K., Li, J., Hu, J., Han, D., Wang, H. \& Chang, X. 2014. Nannochloropsis genomes reveal evolution of microalgal oleaginous traits. PLoS Genetics 10(1): e1004094.

Wijffels, R.H., Barbosa, M.J. \& Eppink, M.H. 2010. Microalgae for the production of bulk chemicals and biofuels. Biofuels Bioproducts and Biorefining 4(3): 287-295.

Ye, Z.W., Jiang, J.G. \& Wu, G.H. 2008. Biosynthesis and regulation of carotenoids in Dunaliella: Progresses and prospects. Biotechnology Advances 26(4): 352-360. 
Aisamuddin Ardi Zainal Abidin \& Zetty Norhana Balia Yusof* Department of Biochemistry

Faculty of Biotechnology and Biomolecular Sciences

Universiti Putra Malaysia

43400 UPM Serdang, Selangor Darul Ehsan

Malaysia

Aisamuddin Ardi Zainal Abidin \& Zetty Norhana Balia Yusof* Laboratory of Marine Biotechnology

Institute of Bioscience

Universiti Putra Malaysia

43400 UPM Serdang, Selangor Darul Ehsan

Malaysia
Chotika Yokthongwattana

Department of Biochemistry

Kasetsart University

Bangkok 10900

Thailand

*Corresponding author; email: zettynorhana@upm.edu.my

Received: 21 October 2018

Accepted: 20 July 2020 